Núm. 175. "... Vaya y venga la tabla al horno..." Cf. Correas, p. 514b: "Vaia i venga la pala al horno, ke nunka la falte pan"; GeróNImo DE Porras, Rimas varias, Antequera, 1639, f. 96: "Que vaya o venga la tabla al horno, / que ya no me falta pan, / que en Belén como unas flores / de balde a todos se da". Cf. también el Entremés del Emperador, en Teatro poético repartido en veintiún entremeses nuevos, Zaragoza, 1658, pp. 150-15l: “...que vaya y venga, todo ruede, / como a mí no me haga mal", y la parodia de Quiñones de Benavente, El mago (Cotarelo, Entremeses, t. 2, p. $581 b$ ): “-Que vaya y venga al Retiro el baile..."

El Colegio de México.

Margtt Frenk Alatorre

\title{
SOBRE EL TEXTO ORIGINAL DE LAS RIMAS DE BÉCQUER (A PROPÓSITO DE LA EDICIÓN DE J. P. DIAZ)
}

Muchos años después de las poesías de Quintana, de Zorrilla y del $P$. Arolas, las Rimas de Bécquer han entrado por fin, al cuidado de José Pedro Díaz, uno de los mejores conocedores actuales del poeta andaluz, en la popular y benemérita colección de Clásicos castellanos ${ }^{1}$. El tomito, de impresión aireada y limpia, es muy agradable. La amplia introducción, en que el editor, resumiendo sus investigaciones previas ${ }^{2}$, estudia la vida (pp. x-lvii) y la poesía (pp. lvii-cx) de Bécquer, está excelentemente hecha y no deja sin tocar ningún aspecto importante.

En las últimas páginas (cx-cxix) de la introducción expone Díaz el criterio de su edición. Los razonamientos que hace y las conclusiones a que llega se traducen, en el cuerpo del volumen, en un texto de las Rimas que no se parece al de ninguna de las ediciones anteriores. Resultado, pues, nada trivial, y que ya por sí merece atención. Ahora bien, este texto me parece incorrecto. Y como lo que está en juego es la autenticidad de la expresión de un poeta muy querido, no creo que esté por demás considerar el problema con algún detenimiento.

Como se sabe, el único texto de las Rimas que se leyó durante casi medio siglo, desde la muerte del poeta hasta 1914, es el que imprimieron las sucesivas ediciones de Obras de Bécquer, a partir de la primera -póstuma-, impresa en Madrid por Fortanet en 1871. Pero en 1914 se publicó en Leipzig la tesis doctoral de Franz Schneider, Gustavo Adolfo Bécquers Leben und Schaffen, que reveló la existencia del Libro de los gorriones, manuscrito autógrafo de las Rimas, fechado en 1868. Después de la primera Guerra mundial, Schneider volvió a describir ese autógrafo en $M P h, 19$ (1921-22), 245-256. El hispanista alemán encontró: 1) que el orden en que aparecían las poesías en el ms. original era completamente distinto del que mostraban los impresos; 2) que en el Libro de los gorriones figuraban tres poesías no incluidas en las

1 Béceuer, Rimas. Ed., introd. y notas de José Pedro Díaz, Espasa-Calpe, Madrid, 1963; exix + 148 pp. (Clás. cast., 158).

2 José Pedro DíAz, Gustavo Adolfo Bécquer, Vida y poesia, Montevideo, 1953, y ediciones posteriores en la $B R H$ de Gredos, Madrid. 
ediciones; y 3) que había no pocas discrepancias textuales entre el ms. y las ediciones (el autógrafo tenía tachaduras y correcciones hechas por una mano que no era la de Bécquer, y las variantes de los impresos coincidían unas veces, otras no, con esas enmiendas del ms.).

Otros trabajos han completado y ampliado los hallazgos de Schneider, particularmente el artículo de Jesús Domínguez Bordona, "El autógrafo de las Rimas de Bécquer", RFE, 10 (1923), 173-179, y el libro de Rubén Benítez, Ensayo de bibliografia razonada de Gustavo Adol fo Bécquer, Buenos Aires, 1961. A ellos viene a añadirse la edición misma de José Pedro Díaz, que tiene, entre otros méritos, el de registrar con bastante escrúpulo las variantes, en notas de pie de página ${ }^{3}$.

¿Quién alteró el orden de las Rimas, suprimió tres poesías y, sobre todo, corrigió en muchos lugares el texto original? Benírez, p. 130, resume asi las respuestas que se han dado a esta triple pregunta: "La responsabilidad de la mayoría de las alteraciones recae sobre los... amigos de Bécquer: Ramón Rodríguez Correa, Narciso Campillo, Augusto Ferrán, quienes con otras [sic] más, se encargaron en 1871 de la primera publicación de las Obras". Díaz, p. cx, dice también: "Como es notorio, la primera edición fue póstuma y estuvo al cuidado de algunos amigos del poeta que no siguieron fielmente el manuscrito autógrafo". Ahora bien, la edición impresa, además de reproducir la

Emplearé en adelante las siguientes abreviaturas:

D. Bordona $=$ el citado artículo de Jesús Domínguez Bordona.

BENítez = el libro de Rubén Benítez, que ofrece no sólo un amplio resumen de la inencontrable tesis de Schneider (pp. 31-46), sino también unas bien pensadas "Notas para una edición de las Rimas de Bécquer" (pp. 130-146), cuya última parte es una utilísima "Tabla de variantes más comunes".

Díaz = el tomo de Clás. cast. que ha dado pie a estos comentarios.

Ms. = el Libro de los gorriones (ms. 13.216 de la B.N.M.).

Ed., Eds. = la ed. de Obras de Bécquer de 1871 , o las eds. que reproducen su texto. Debo hacer constar que me baso en los datos de D. Bordona, Benítez y Díaz. Este último declara (pp. cxii-cxiii) que "las variantes que presentan las ediciones póstumas" han sido verificadas por él "sobre un ejemplar de la segunda edición (1877)" [entiéndase la 2" ed. española: la segunda, en rigor, fue la de "El Siglo XIX", México, 1872]. En cambio, D. Bordona verificó esas variantes con la ed. de Madrid, 1907, "que es copia de las anteriores". BENítez, por su parte, dice en la mencionada "Tabla" que confronta las variantes con "las ediciones corrientes", entre las cuales incluye, desconcertantemente, no sólo "las... que copian a la primera", sino también las que siguen a D. Bordona. Es posible que algunas de las discre. pancias que se observan entre D. Bordona, Benitez y Diaz se deban al hecho de que han manejado ediciones distintas. Hay, pues, un margen de error para las lecciones que atribuyo a las "Eds." en las páginas que van a seguir, pero confio en que ese margen sea estrecho, ya que las variantes que en las Eds. encuentran mis tres guías son fundamentalmente las mismas.-Desde luego, las lecciones que importan son las de la 1: ed., de 1871, que, por lo visto, ninguno de los tres tuvo oportunidad de consultar. Habria que ver, por ejemplo, si en ella figuran ya "variantes" que no son sino erratas, como oirlo en vez de oido (1:12), agrupan en vez de agrupa (3:60) o tenia en vez de tenias (41:3). (Las dos primeras erratas son registradas por D. Bordona y por Díaz; la tercera es registrada sólo por Diaz; según D. Bordona y Benitez, en las Eds. se lee tenía, que es lo correcto). No cuento como errata la lección intervalos que dan las Eds. en 73:14, pues es claro que, con acento gráfico o sin él hay que leer intérvalos, so pena de estropear al mismo tiempo el metro y la asonancia. (Cf. también infra, p. 410, nota 24). En mis referencias adopto un sistema simplificado: "3:60" significa Rima $I I I$, verso 60 , etc. 
mayoría de las enmiendas que aparecen en el Ms., añade otras, hecho que explica Benítez diciendo que los amigos de Bécquer no sólo "efectuaron los ya indicados cambios en el manuscrito mismo", sino también "una segunda corrección antes de imprimir la obra" (p. 137), o incluso en "las pruebas de impresión" (p. 130). "Se comprende -dice por su parte D. BordonA, p. 174- que las variantes que en las ediciones aparecen [y que no constan en el Ms.] deben proceder de otra copia, que se utilizaría para la imprenta", y "con gran probabilidad" pueden atribuirse a las mismas manos que intervinieron en el Ms.

Desgraciadamente no se conservan las pruebas de imprenta de la edición de 1871, ni la copia que se mandó a los impresores, documentos que sin duda arrojarían mucha luz sobre la etapa intermedia entre el Ms. corregido y la versión vulgata de las Rimas. Pero nos queda el Ms. $\mathrm{X}$ lo que en él se observa es que sobre muchas palabras y aun versos enteros, escritos con "la letra del poeta..., suave y redondeada", se han hecho enmiendas con otra letra, "angulosa y de fuertes trazos" (Benítez, p. 135). Schneider creyó que esta letra era la de Augusto Ferrán4. Pero D. Bondona, el único que se ha tomado el trabajo de comparar la escritura de Bécquer con la de sus amigos", llegó a una conclusión distinta: "Un examen detenido de los autógrafos de amigos y contemporáneos del poeta, da el convencimiento absolu to de que tales enmiendas deben atribuirse a Narciso Campillo. Lo prueba la identidad de la letra"6. Nadie, que yo sepa, ha refutado esta ca-

4 Seguramente se atuvo a lo que dice Rodríguez Correa en el prólogo de la ed. de 1871: "No menos alabanza merece el señor D. Augusto Ferrán, inseparable amigo del malogrado Bécquer, que no se ha dado punto de reposo en el asiduo trabajo de allegar materiales dispersos, coleccionarlos, vigilar la impresión y demás tareas propias de estos difíciles y dolorosos casos, ayudado del señor Campillo, tan insigne poeta como leal amigo". Pero Rodríguez Correa habla concretamente del trabajo de "allegar materiales" (las Obras contienen no sólo las Rimas, para las cuales no hacía falta esa tarea de recopilación, sino muchos escritos en prosa, publicados en diferentes periódicos y revistas). Por lo demás, el prologuista se guarda mucho de decir que alguien haya metido mano en los originales. Al contrario, asegura que todo se publica "sin la menor enmienda", "tal cual lo hemos hallado". (Cf. las citas recogidas por Benítez, p. 137).

5 Ni en la Bibliografía de Benítez ni en el artículo de don HoMero Serís, "Estado actual de los estudios sobre Bécquer...", HJS, 2, 377-388, encuentro mención de ningún otro estudioso que lo haya hecho. Verdad es que D. Bordona no publica pruebas de su labor de cotejo, y no nos queda más remedio que atenernos a su palabra. Sería necesario acudir, como dice BENítez, p. 135, a "la experiencia de un perito calígrafo": su trabajo, que ciertamente no sería cosa del otro mundo, disiparía las dudas que todavía puedan caber.

$6 \mathrm{Y}$ "lo confirma" la anécdota recogida a continuación por D. BordonA, el cual la toma de un artículo de Eduardo Lustonó publicado en 1901: "Un día se presentó Bécquer en casa de Campillo, y, al preguntarle éste por su salud, le contestó: -Estoy haciendo la maleta para el viaje. Dentro de poco, me muero... Liados en este pañuelo vienen mis versos y prosa. Corrígelos, como siempre; acaba lo que no esté concluido; y si antes me entierran, tú publica lo que te guste, y en paz".-Aun antes de dar a la luz (en 1872) su Retórica y Poética, Campillo, "con la autoridad que le prestaba su título de catedrático, fue el mentor de varios de aquellos postrománticos, como Arístides Pongilioni (otro buen amigo de Bécquer), impulsivos e indisciplinados, que fiaban la mayor parte de su trabajo a la intuición y fantasía propias" (D. BordonA, pp. 173-174). (Claro que de Bécquer mismo no se puede 
tegórica afirmación. Benítez, con loable cautela, prefiere hablar del "amigo anónimo" o del "corrector", pero José María de Cossío, Gerardo Diego y Rafael Alberti, para poner tres ejemplos no vulgares, aceptan como bien averiguado el hecho de que el corrector fue Campillo ${ }^{7}$.

Parecía, pues, liquidado el problema: lo único que había que hacer era reproducir simplemente el Libro de los gorriones, eliminando de él las enmiendas ajenas. Es, por cierto, lo que se ha hecho ya en algunas ediciones y en no pocos estudios. Pero aquí es donde entra justamente la novedad del criterio de Díaz, que no acepta ni el texto de las Eds. ni el del Ms. original, sino un texto intermedio. Véase cómo expone él mismo este criterio (pp. cxvii-cxix):

En general, y a partir del trabajo de J. Domínguez Bordona, las correcciones del manuscrito fueron atribuidas a los amigos de Bécquer que prepararon la edición de 187l. Nosotros mismos afirmamos que podrían corresponder a manos diferentes, y el profesor Benítez señaló la posibilidad de distinguir entre correcciones de Bécquer y de otra mano.

Por nuestra parte, y después de un minucioso análisis de ese texto, llegamos a la conclusión de que las correcciones manuscritas deben ser consideradas de la misma mano que el original, es decir, del mismo Bécquer. En primer lugar, porque en todas ellas reconocemos grafías tipo que se dan en otros momentos del original becqueriano, sea en el ms. de las rimas, sea en otras páginas en prosa de El libro de los gorriones. $\mathrm{Y}$ en segundo lugar, porque en todas ellas se puede reconocer la voluntad de ajustar el verso de que se trata al tono que reconocemos como dominante y característico de nuestro autor.

Algo muy distinto ocurre con las variantes que aparecen en la Ed. Éstas suelen tener el carácter de correcciones académicas y exteriores. A menudo imponen un tono enfático y aun alteran el sentido original.

En consecuencia, el texto auténtico de Bécquer es, para Díaz, el del Ms. con todas las correcciones que en él figuran, pero $\sin$ las enmiendas introducidas en las Eds., y ése es el que aparece en el volumen aquí comentado. Yo creo que Díaz se equivoca, y así espero demostrarlo en las páginas siguientes. Pero antes, es preciso examinar con atención los tres párrafos que acabo de transcribir.

En el primero de ellos, la referencia a Rubén Benítez puede prestarse a una mala interpretación. BENíTEz, pp. 135-136, no habla sino de un solo caso en que la corrección hecha en el Ms. "pertenece a Bécquer con seguridad". A diferencia de lo que hace "el corrector desconocido, [que] acostumbra tachar las palabras que va a modificar, escribiendo la enmienda entre líneas o al margen", en los versos de la

decir así como asi que haya sido un poeta meramente "intuitivo", ni "indisciplinado" en la factura de sus versos).

7 José María de Cossío, "Hojas de un álbum", CoE, l (1940-41), 180-183; GERARdo Diego, "Bécquer restaurado", La Nación, Buenos Aires, 25 de abril de 1943 (no he podido leer este artículo; me baso en el resumen que de él ofrece Bevítez, p. 23, núm. 14); Rafael Alberti, ed. de las Rimas de la editorial Pleamar, Buenos Aires, 1944. 
Rima 3: "descanso en que el espíritu / recobra su vigor", aparece a la izquierda "un asterisco que remite al margen, también izquierdo, de la hoja", donde se lee esta segunda versión: "oasis que al espíritu / devuelve su vigor"; pero la versión primera no está tachada9. "Con menos seguridad", prosigue Benítez, pueden atribuirse a Bécquer las correcciones de 57:4 y de 71:21, y "con mucha mayor precaución" podría admitirse como de Bécquer la de 66:9. Y eso es todo ${ }^{10}$.

En el segundo de los párrafos transcritos, Díaz declara las dos razones que tiene para atribuir a Bécquer las correcciones del Ms.: las "grafías tipo" y la "voluntad de tono". El argumento de las grafías no se entiende fácilmente. Desde luego, no parece muy técnico. No creo que signifique mucho más de lo que en forma más clara ya había reconocido BENíTEz, p. 135: "algunas grafías presentan características comunes, propias sin duda de la época: la $d$, por ejemplo, que ambos [el poeta y el corrector] dibujan como una delta griega minúscula". $\mathrm{Y}$, sobre todo, no hace Díaz el menor intento de refutar lo dicho por los investigadores que lo precedieron, los cuales encontraron tan notorias diferencias entre la letra "suave y redondeada" de Bécquer y la "angulosa y de fuertes trazos" del corrector. En cuanto a la "voluntad de ajustar el verso... al tono que reconocemos como dominante y característico de nuestro autor", ¿no se trata de un razonamiento circular? Porque si desde adolescentes hemos leído, pongamos por caso, "y entonces comprendí por qué se llora, / y entonces comprendí por qué se mata" (42:7-8), es claro que habremos integrado esos versos a nuestra impresión de lo que es "característico" de Bécquer, y encontraremos que la otra versión, "y se me reveló por qué se llora, / y comprendí una vez por qué se mata", tiene un tono de tanteo, menos "característico", menos acorde con nuestra idea de "lo becqueriano"11. O sea

8. Son los versos 64-65, y no 63-64, como dice Benítez, que probablemente no ha contado el v. 33, "Tal es la inspiración".-Aprovecho esta oportunidad para hacer una sugerencia a la editorial Espasa-Calpe: que en las obras poéticas, los versos de una misma composición se impriman con numeración corrida (como se hizo, por ejemplo, en el Garcilaso de don Tomás Navarro), en lugar de iniciarla de nuevo cuando la poesía pasa de uná página a otra.

9 Benítez, en la "Tabla", pone "descanso en que el espiritu / recobra su vigor" en la columna de "Versos que Domínguez Bordona da como originales". Me parece de justicia hacer notar que D. Bordona, p. 175, dice expresamente: "La correc. ción de los versos 64 y 65: "Oasis que al espíritu / devuelve su vigor», es de Bécquer".

10 Yo no creo que puedan atribuírsele a él las de 57:4 y 71:21 (cf. infra, p. 409, nota 22 , y p. 415 , nota 39 , hacia el final). En cuanto a la otra $(66: 9)$, lo que ocurre es que la palabra triste está sobre otra completamente ilegible a causa de la tacha. dura. O sea que aqui tenemos que contentarnos con la enmienda del corrector, faute de mieux.

11 Este sentimiento, muy natural, es el que hace que Rafael Alberti, en la ed. de Buenos Aires, 1944, la "primera versión original" de las Rimas (o sea: la primera que aprovecha las lecturas del Ms. dadas por D. Bordona), encuentre "justo y necesario reproducir", en un Apéndice, "los versos corregidos por Campillo -algunos con verdadero acierto--, esos que tuvieron la suerte de aparecer hasta ahora como de Bécquer, y que seguramente no va a ser posible ya arrancar -pareciéndo. nos, por otra parte, inútil el intento- de la memoria de tantos fieles apasionados del poeta". 
que deberemos primero deshabituarnos del prejuicio de que el texto más conocido es también el más "característico".

Por último, Díaz encuentra que hay una gran diferencia entre las correcciones hechas materialmente en el Ms. y las que sólo aparecen en las Eds. Yo no veo tal diferencia. En mi conclusión (infra, pp. 416417) trataré de demostrar que tan "académicas" son unas como otras, y que si las de las Eds. a veces "alteran el sentido original", lo mismo, exactamente, cabe decir de las que figuran ya en el Ms.

$\mathrm{He}$ recordado cómo Schneider, al cotejar con las Eds. el autógrafo por él descubierto, encontró tres alteraciones principales: 1) el orden de las poesías; 2) la supresión de tres de ellas; y 3) las enmiendas. En cuanto a lo primero, poco hay que decir. Díaz está de acuerdo en que la secuencia que se dio a las Rimas en las Eds. es obra de los amigos de Bécquer, y resume (pp. xci-xcii) las observaciones de Gerardo Diego sobre el hilo biográfico-argumental que ellos se esforzaron en darles: poesía y amor (rimas 1-11), amor afirmativo y esperanzado (12-29), fracaso del amor (30-51), soledad y desesperación (52-76). Evidentemente, Campillo y compañía trataron de imponer a ese puñado de versos cierta "dignidad" poemática y de acercarlos de alguna manera al Intermezzo de Heine. Una buena edición no debiera vacilar en volver al orden -o desorden, si se quiere- que las poesías guardan en el Libro de los gorriones, tanto más cuanto que "las poesías agrupadas según un criterio puramente argumental pueden suscitar, como ha pasado, caprichosas interpretaciones sobre la relación existente entre los hechos reales de la vida del poeta, y la trasposición artística de los mismos" 12 .

En cuanto a la supresión de tres de las setenta y nueve poesías que contiene el Libro de los gorriones, creo que todos están de acuerdo en que se debió a que las tres presentaban "un tono amargo y sarcástico que no parec[ía] condecir con la falseada imagen del poeta", imagen de dulce y grave melancolía ${ }^{13}$. Ocioso es decir que las tres poesías condenadas deben recobrar su sitio en las ediciones de Bécquer ${ }^{14}$. Lo

12 Palabras de Benítez, p. 138. Véase también lo que dice R. Balbín de Lucas al final de su artículo "Sobre la influencia de Augusto Ferrán en la Rima XLVII de Bécquer", RFE, 26 (1942), 319-334: "El orden en que los amigos de Gustavo Adolfo editaron las Rimas, al darles una construcción poemática de que carecen en el Libro de los gorriones, tergiversó la interpretación de algunas de las compo. siciones $\mathrm{y}$, entre ellas, falseó la matización temática de la Rima XLVII [־Yo me he asomado a las profundas simas... $]$, que, colocada entre otras dos que cantan la ingratitud amorosa de una mujer, ha venido leyéndose con sentido análogo", cuando lo que esa Rima expresa es un "sentimiento de admiración" por la hondura insondable del corazón humano.

13 Benítez, p. 140. Cf. ya F. Schnetder, $M P h$, 19 (1921-22), pp. 247-248: "The reason for this suppression is quite evident: their tone was too bitter and ironical; and Bécquer was to be presented to the world in his more congenial aspect of grave and sentimental dreamer". Todo lo cual constituye una refutación del argumento de Díaz al que poco antes me refería: la "voluntad" de ajustarse al "tono" becqueriano no tiene que ser necesariamente obra de Bécquer.

14 Díaz les da, en la suya, los números LXXVII ("Dices que tienes corazón, y sólo / lo dices porque sientes sus latidos..."), LXXVIII ("Fingiendo realidades...") y LXXIX ("Una mujer me ha envenenado el alma..."). Esta última se conocia, 
único que hay que añadir es que, por una vez, Díaz mismo -venciendo, como él dice, "un escrúpulo menor"- va contra su propio criterio y recoge la poesía "Una mujer me ha envenenado el alma...", a pesar de estar tachada en el Ms. (por Bécquer, según cree él tan decididamente) "con dos gruesos trazos en cruz".

Y llegamos asi al tercer punto: las enmiendas. Sobre ellas se posee una buena información. Schneider, al dar noticia del Libro de los gorriones, inició la labor registrando los cambios hechos en nueve de las Rimas $(2,10,12,18,22,24,42,65$ y 75$)$. D. Bordona se propuso publicar "todas las variantes" que ofrece el autógrafo. Aunque muchas se le escaparon ${ }^{15}$, su labor fue muy meritoria, y su artículo constituyó el punto de arranque para la primera edición en que se intentó volver al texto original de Bécquer, la de Rafael Alberti ${ }^{16}$. Finalmente, Benítez y Díaz mismo proporcionan casi toda la información que se puede desear al respecto. Pues bien, creo que basta analizar con algún cuidado todas las enmiendas para llegar a la conclusión de que no se deben a Bécquer.

Ya he dicho cómo, en mi opinión, Díaz no demuestra su afirmación de que la letra de las correcciones es del poeta. $\mathrm{Y}$ también he recordado cómo D. Bordona las atribuye categóricamente a la mano de Narciso Campillo. Yo no tengo posibilidad de aportar ninguna prueba en favor de esta identificación, ni, en rigor, estoy interesado en encontrarla. Me basta con saber que las enmiendas del Ms. no fueron hechas por Bécquer. Si en adelante llamo "Campillo" al corrector, lo hago porque me atengo al dictamen de quien estudió la letra de las correcciones, y también porque éstas suelen estar de acuerdo con lo que se sabe de la postura académica de Campillo. (Pero lo mismo da si algún día se averigua que no fue él quien las hizo). En otras palabras, tomo la afirmación de $\mathrm{D}$. Bordona como un simple punto de partida, y en las páginas que siguen trataré de demostrar que las correcciones de Campillo son unas veces indiferentes, pero otras veces alteran el texto original (sin mejorarlo nunca) e incluso lo estropean pura y simplemente ${ }^{17}$. Como, por otra parte, para las variantes que aparecen en las

aunque con algún cambio ("Una mujer envenenó mi alma...") desde 1901, publicada en un artículo periodístico por Eduardo Lustonó (según D. BordonA, p. 178) . Fue recogida por el mismo Lustonó en su Cancionero de amores, Madrid, 1903 (Benitez, p. 56, nota), apareció luego en La Esfera, Madrid, 5 de diciembre de 1914 (Benítez, p. 26, núm. 30), y pasó después, irresponsablemente, al tomo 1 de las Obras completas de Rubén Dario publicadas por Rubén Darío Sánchez, Madrid, 1921 (según D. Borpona, p. 179).

15 Cf. infra, nota 23.

16 Cf. supra, p. 404, nota 7. Véase la reseña de J. F. Gatri en $R F H, 6$ (1944), 293-294.

17 No quiero pecar de intransigencia. Admito que la corrección "y se me reveló por qué se llora, / y comprendí una vez por qué se mata" > "y entonces compren. di por qué se llora, / y entonces comprendi por qué se mata" (42:7-8) podría ser defendida como más fluida y armoniosa que el texto original. En casos como éste -y no encuentro que abunden- habrá pensado Alberti (cf. supra, p. 405, nota 11) al hablar del "verdadero acierto" de algunas enmiendas. Pero el hecho es que ni siquiera éstas eran necesarias. El final de la Rima 75 dice así en el Ms. "Yo no sé si ese mundo de visiones / vive fuera o va dentro de nosotros: / lo que sé es que conozco a muchas gentes / a quienes no conozco". Campillo corrigio: "Pero sé 
Eds. y no en el Ms. acepto la opinión de D. Bordona (p. 174) de que "pueden, con gran probabilidad, atribuirse también a Campillo", no haré, en general, distinción entre unas y otras. Mi hipótesis de trabajo es que todas las correcciones se deben a "Campillo". Pero, como ya he dicho, trataré de demostrar en mi conclusión (pp. 416-417) que esa hipótesis ha sido correcta.

Hay, en primer lugar, las correcciones meramente caprichosas, que, obedeciendo a minúsculas preferencias personales de Campillo, no afectan en forma notable, ni para bien ni para mal, el texto original de Bécquer. Algunos ejemplos: "y apenas... / podria al oído cantártelo a solas", cambiando en "y apenas... / pudiera" (1:12); "y el paso le dejé" > "y el paso la dejé" (32:2); "del altar que le alcé" > "que la alcé" (48:5) 18; "me partió a sangre fría el corazón" > "partióme a sangre fría..." (46:4); "pero otra luz" > "mas otra luz" (71:11); "le acabo" > "le agoto" (64:6); "alguna vez me acuerdo con envidia de aquel rincón" > "recuerdo con envidia / aquel rincón" (76:3940) ; "de la sonrisa última" > "de la postrer sonrisa" (76:13); "con el callado paso que se llega" > "que llegamos" (76:27) ${ }^{19}$; "Ay! y es verdad..." > "Ay! es verdad..." (45:13).

que conozco a muchas gentes..." Me sorprende que Alberti, en su ed. cit., haya preferido aquí la versión enmendada, que para mí es no sólo innecesaria, sino menos hermosa, por menos eficaz. A mí me parece que cuando Campillo consigue una mayor naturalidad prosódica o sintáctica, lo hace casi siempre a expensas de algo más importante. Así en el caso de 18:11, que adelante comentaré (p. 412): el heptasílabo "tal vez allí dormía" es más fluido que "dormir parecía al blando", pero el resultado poético de la enmienda es desastroso. En la utilísima Concordancia de las Rimas que EDmund L. King ofrece al final de su libro Gustavo Adolfo Bécquer from painter to poet, México, 1953, se transcribe primero el texto original y luego la enmienda de Campillo, cuando la hay, porque así -dice King-" "the reader will be able to see at once how in some instances Bécquer's most characteristic touches have been obliterated, albeit in the interest of more facile or even more correct readings".-Hay un solo caso en que la mano de Campillo parece haber hecho una corrección que se imponía. Si es verdad que Bécquer escribió "Y ella impávida sigue su camino, / feliz, risueña, impávida..." (46:5-6), Campillo tuvo razón para su enmienda: "Y ella prosigue alegre su camino..." Sería preciso, sin embargo, ver más de cerca lo que ha ocurrido aquí. Me extraña que ni $D$. Bondona ni Benítez registren ninguna variante para la Rima 46.

$18 \mathrm{He}$ dicho que se trata de correcciones que no afectan ni para bien ni para mal el texto de Bécquer. De hecho, a mi oído mexicano le ofende el laísmo, pero quizá a los lectores españoles de Bécquer les tenga sin cuidado. Por otra parte, a mi oído mexicano le molesta también el leísmo, pero esto no me da derecho para rechazar el leísmo ajeno. Campillo, loísta como yo, convirtió casi sistemáticamente en lo el le acusativo del poeta: "escribirle" (1:5), "encerrarle" (1:10), "le guíe" (3:27), "contemplarle" (45:9), "buscándole" (56:10), "le llamo" (64:5), "le acabó" (64:6). Benitez, p. 138, dice que en 9:8 las Eds. respetan el texto original, "le besa", pero en la Tabla pone como lección de las Eds. "lo besa"; y no dice nada de "aspírale", "acércale" y "déjale" (58:2-3), ni de "tapiáronle" (73:66). De todos estos casos de $l e>l o$, DíAz sólo recoge uno: el de 1:10. En cambio, ninguno de los casos de laísmo anotados por Díaz aparece en Benítez. (Todo esto podrá parecer minucia. Pero creo que ha hecho muy bien Dámaso Alonso en eliminar el leísmo de Chacón para restaurar el loísmo de Góngora. Cf. su ed. del Romance de Angélica y Medoro, Madrid, 1961, p. 77, nota 72).

19 Ésta es la corrección hecha en el Ms.; en las Eds. hay una alteración aún mayor: "como quien llega con callada planta". 
Claro que las correcciones que acabo de mencionar no son en realidad tan indiferentes o anodinas: partióme podrá ser, semánticamente, lo mismo que me partió, y agotar (un tesoro) lo mismo que acabar, pero de hecho no quieren decir lo mismo; conllevan ya una actitud distinta y son índices de un gusto ajeno -más tieso, más retórico, más cargado de "literatura"- indebidamente superpuesto al del poeta, y en este sentido podemos decir, sin exageración, que mas no es lo mismo que pero, ni postrero lo mismo que último. Sin embargo, todavía se podría argumentar que, aunque innecesarias, estas correcciones respetan la "idea" del poeta. Pero las más de las veces no es así. Por lo general, en una forma o en otra, le hacen decir a Bécquer lo que él no quiso. Algunos ejemplos: "Mientras la humana ciencia no descubra" $>$ "Mientras la ciencia a descubrir no alcance" (4:13); "y no te encuentro a ti, no; es tu mirada..." $20>$ "mas no te encuentro a ti; que es tu mirada..." (14:7); "y andabais allí a caza" > "y andáis por allí a caza" (40:21) ; "de confesar que me has querido un poco" > "que me quisiste un poco" (44:6); "yo sé cuando tú sueñas" > "yo sé lo que tú sueñas" (59:9) ; "tú lo sabes apenas" > "tú acaso lo sospechas" (59:7 y 15) ; "a veces me acuerdo" > "a solas me acuerdo" (73:86). En la Rima 10 hay una supresión absolutamente gratuita y sin excusa. El último verso: "Dime?... - -Silencio! Es el amor que pasa", hendecasílabo como todos los de este breve y hermoso poema, quedó reducido a heptasílabo por la eliminación de las dos primeras palabras ${ }^{21}$.

En muchas de las enmiendas no es difícil descubrir el afán purista o académico de Campillo. Son retoques que manifiestan un deseo de mayor propiedad, de mayor corrección y de una lógica más racional, o bien un prurito de evitar "cacofonías" desaconsejadas en las precep. tivas. He aquí las muestras más evidentes de ese afán: “donde al polvo volverá" > "donde a caer volverá" (2:8) (le sonaría mal a Campillo la repetición de sonidos "polvo volverá"); "Tenías que estrellarte o que abatirme" > "que estrellarte o abatirme" (41:3); "Lo que sé es que..."> "Pero sé que..." (75:19); "porque aunque es la verdad que..." > "pues aunque..." (57:4) ${ }^{22}$; "mientras se sienta que se rie el alma" > "mientras sintamos que se alegra el alma" (4:21) ${ }^{23}$; "tan

20 Cf. 11:4: "¿A mí me buscas? -No es a ti, no".

21 Reconozco que en este caso será muy difícil probar que la tachadura es de la mano de Campillo. (Aquí, y en otros lugares, un análisis químico de la tinta podría disipar dudas). Varias de las Rimas $(6,9,30,79)$ están escritas en ocho hendecasílabos, aunque también hay dos (la 46 y la 62) que constan de siete hendecasílabos y un heptasílabo final. J. M. DE Cossio, en el lugar cit. supra, p. 404, nota 7, publica en facsímil un autógrafo de la Rima 10, tomado de un álbum en que figuran poesías fechadas entre 1860 y 1870 . En el verso final se lee: "Dime? $\rightarrow_{-}$Silencio! Es el amor que pasa!", exactamente lo mismo que en el Libro de los gorriones antes de ser enmendado. La tachadura se debió a Campillo, según Cossío, el cual comenta: "Creo que no acompañó el acierto a esta corrección".

22 La palabra pues, dice Benírez, p. 135, "mejora el sentido del texto". Yo no lo creo. Hay un ligero cambio de sentido, pero tan normal y aceptable es el pues como el porque. En todo caso, Benítez, después de decir que la única corrección del Ms. que "pertenece a Bécquer con seguridad" es la de 3:64-65, pone este pues entre las poquísimas que "con mênos seguridad" pueden atribuírsele.

${ }_{23}$ La corrección no se hizo en el Ms., como indica D. BordonA, sino eu el im- 
sólo al genio es dado / a un yugo atar las dos" > "tan sólo el genio puede / a un yugo..." (3:69-70) (para evitar la repetición de la preposición); "a apagar la sed con ella" > "en ella" (12:31), y en cambio "risas que se desmienten en los ojos" > "con los ojos" (44:4) (afán de "propiedad")

Algunas alteraciones se deben a mero descuido: en 12:24, "que parecen sus pupilas" se convierte en "tus pupilas" (bastaba un poco de atención para ver que sus pupilas significa 'las pupilas de tus ojos'); y de manera semejante, en 27:19, "tranquilo fulgor vierten (se entiende: "tus ojos") pasa a ser "tranquilo fulgor viertes" (!) ${ }^{24}$.

En el comienzo de la Rima 62: "Primero es un albor trémulo y vago..., / luego chispea, crece y se difunde / en gigante explosión de claridad", el adjetivo gigante ${ }^{25}$ no está puesto a humo de pajas, sino que subraya el aumento de la luz del sol, a partir del vago albor inicial. Campillo rebaja la expresión: "y crece y se dilata / en ardiente explosión de claridad".

Una y otra vez, los giros atrevidos o poco usuales quedan mitigados por el corrector. ¿Dice Bécquer que "se rie el alma”? ¡Pues a rectificarlo! Es más propio decir que "se alegra el alma" (4:21). Los ejemplos abundan: los dos "se me antoja posible" de 8:5 y 14 se convierten en descoloridos "me parece posible"; "la vista clavo" > "la vista fijo" (14:5); "la brilladora lumbre" > "la brilladora luz" (62:5) (porque, dicho del sol, luz es lo indicado); "el perfume beber" $>$ "el perfume aspirar" (67:8) (porque el perfume no se bebe); "Yo ya me he embarcado; por señas que aún tengo..." > "Ha tiempo lo hice; por cierto que aún tengo..." (72:25). "La noche se entraba, / el sol se habia puesto", escribió Bécquer (73:74). Si la noche se entraba, pensaría Campillo, sobra decir que el sol se había puesto, y así corrige intrépidamente: "La noche se entraba, / reinaba el silencio" (corrección absurda, pues el silencio ya reinaba en el cementerio desde que se había alejado el sepulturero).

Al mismo afán purista parecen responder las correcciones del final

preso, como señala Díaz. Este dice (p. cxi) que D. Bordona no recogió todas las variantes del Ms., pero no lo acusa de dar indicaciones falsas. Hay, en efecto, algunas variantes que D. Bordona no recoge (v.gr. 7:8, 28:17, 34:19, 45:13, 55:3), pero también algún caso en que D. Bordona indica variantes que Diaz omite $(47: 6$ " $y$ me incliné un momento" > Eds. "y me incliné por verlo).

24 Otras lecciones evidentemente erradas no sé muy bien cómo se explican, pero, desde luego, habría que corregirlas. Según Bewirez, el Ms. dice en 3:27 "sin riendas que le guie / caballo volador", y las Eds. corrigen "sin rienda que lo guíe" (podria ser también "sin riendas que le guien"). El verso inicial de la Rima 61 no puede ser " $A l$ ver mis horas de fiebre", sino " $A$ ver mis horas..." (la frase, sin el hipérbaton becqueriano, dice: "Quién se sentará a la orilla de mi lecho $a$ ver pasar, lentas, mis horas de fiebre e insomnio?'). En 41:6 thay que leer aguarda, como trae la ed. de DíAz, o más bien aguanta, como cita él mismo en la p. xcvi ("tú eras el oceano y yo la enhiesta ( roca que firme aguanta su vaivén") ? Otras cosas que se leen en esta edición son simples erratas de imprenta, como Nube por Nubes (52:9) y abrazada por abrasada (20:2). En la Rima 15, estrofa 2, hay que corregir, sin duda: "Tú, sombra aérea, que cuantas veces..."

25 Cf. "Yo sé un himno gigante y extraño" (1:1). "gigante ola" (2:9), "gigante voz" (3:34). 
de la Rima 73: "¿Todo es sin espiritu...? / No sé, pero hay algo..., / algo que repugna, / aunque es fuerza hacerlo, / a dejar tan tristes, / tan solos los muertos" > "¿Todo es vil materia...? / No sé, pero hay algo... / que al par nos infunde / repugnancia y duelo / al dejar tan tristes...", pues seguramente a Campillo le molestó, por desusado, el giro "algo que repugna a dejar solos los muertos".

En algunos casos parece que lo que escandalizó a Campillo fue el hipérbaton de Bécquer, que ciertamente suele ser violento ${ }^{26}$. Las siguientes alteraciones vendrian a demostrarlo: "Sobre un volcán hasta encontrarla ahora / nunca he visto una flor" $>$ "Nunca hasta ahora contemplé en el mundo / junto al volcán la flor" (22:3-4) ${ }^{27}$. "Mi espiritu... / se sentará a las puertas de la muerte / que llames a esperar", escribió Bécquer $(37: 7-8)$, con un hipérbaton muy frecuente en él ${ }^{28}$; pero Campillo lo corrige: "se sentará a las puertas de la muerte / esperándote allá" 29 .

Ciertas alteraciones se deben a que el oído de Campillo no funcionaba de la misma manera que el de Bécquer en cuanto a prosodia y ortoepeya. Bécquer, por ejemplo, "sentía" de cuatro sílabas la palabra silueta (si-lu-e-ta) ${ }^{30}$, y así, sin necesidad de acudir al signo gráfico de diéresis, pudo escribir el heptasílabo "Deformes siluetas" (3:9) y el hendecasílabo "Cuántas veces trazó mi silueta" (70:5). Pero Campillo no sentía allí sino tres sílabas y, claro, tuvo que tropezar en los versos. En el primero de ellos imprimió silüetas, con diéresis ${ }^{31}$; en el segundo

26 Cf. DÁmaso Alonso, Poesia española: Ensayo de métodos y limites estilisticos, Madrid, 1950, pp. 52-53.

27 Insatisfecho aún, quizá por la vecindad de mundo y junto, corrigió en la Ed. "Nunca hasta ahora contemplé en la tierra..."

28 Cf. 53:2 "sus nidos a colgar", 54:2 "del pasado a evocar", etc.

${ }_{29}$ También aquí muestran las Eds. una tercera lección: "sentándose a las puer. tas de la muerte, / allí te esperará". (La razón de esta tercera lectura puede ser la "impropiedad" del adverbio allá: cf. la enmienda ms. de 24:15, "y al juntarse alla en el cielo", re-corregida en "y al juntarse alli en el cielo", que es como se lee en las Eds.).- Me imagino que también le chocó a Campillo la sintaxis de "con genio es muy contado el que la escribe / y con oro cualquiera hace poesia" (26:13-14), y que por eso subrayó la escribe y hace; pero esta vez, por lo visto, no discurrió una frase más lógica (las Eds. se limitan a poner "quien la escribe" en vez de "el que la escribe", lo cual deja intacto el hipérbaton). El resultado es que DíAz, fiel a su creencia de que todo cuanto hay en el Ms. es de la mano de Bécquer, imprime en cursiva la escribe y hace, lo cual es absurdo y desconcertante.

so Tal vez haya que decirlo de manera menos categórica. En varios pasajes Bécquer mide violeta con cuatro sílabas (cf. nota siguiente), pero en 5:22 mide violeta, con tres.

31 Êsta no figura en el Ms., y por consiguiente Díaz imprime siluetas, sin ella. Díaz, además, anota cuidadosamente otros casos en que las Eds. ponen diéresis que faltan en el Ms. (ruinas 5:24, suave 13:2 y 27:11). Me sorprende, por tanto, que se aparte de su criterio e imprima rüidos en $73: 19$, a pesar de que, como él mismo dice en nota a ese verso, "en el $\mathrm{ms}$. no consta la diéresis". Si sintió necesidad de ponerla aqui - ¿para ayudar al lector?-, debió ponerla asimismo en silüetas, rüinas y süäze, como también en embrïaguez $3: 31$ y 43:6, armonïoso 3:50, armonïosas 24:8, sonrïendo $72: 23$, sonriéndose $49: 3$, palabras estas últimas que están en la misma situación que rüidos, o sea que no tienen diéresis ni en el Ms. ni en las Eds.-Diaz no imprime con diéresis, en general, sino las palabras que aparecen con ella en el Ms.: idïoma 1:6, vïoleta $13: 8$ y zïoletas $72: 2$, las cuales no la tienen en las Eds. 
empleó un remedio más enérgico e introdujo en el Ms. esta corrección: "Cuántas veces trazó mi triste sombra". Otro tanto hizo con el hendecasílabo "En la clave del arco ruinoso" (45:1), donde el adjetivo ruinoso (ru-i-no-so), que él sentiría trisilábico, quedó convertido en un desmañado mal seguro (que no es lo que Bécquer quería decir, pues mal seguro puede estar hasta un arco hecho ayer). Otra muestra de la dureza de oído de Campillo nos la da el estropicio que hizo en el octosílabo "y al reunirse en el cielo" (24:15), metamorfoseado ripiosamente en "y al juntarse allá en el cielo". (Bécquer decía evidentemente re-unirse $)^{32}$. En cambio, Bécquer hacía sinéresis en la palabra creo, y Campillo, que tenía hábitos distintos, se lo corrigió en dos ocasiones: "siempre valdrá lo que yo creo que calla" > "siempre valdrá, a mi ver, lo que ella calla" (34:19) y "creo que me saludaban" $>$ "vi que me saludaban". (70:36), pero dejó intacto el creo monosilábico en 40:17. Bécquer hacía también sinéresis en la desinencia $-i a$, y como esto no era del agrado de Campillo; el verso “¡No podia ser!” de 41:4, 8 y 12 quedó transformado por él las tres veces en "¡No pudo ser!"33 Lo mismo ocurrió, seguramente, con el parecia de 18:11: "dormir parecia al blando / arrullo de sus labios entreabiertos" > "tal vez alli dormía / al soplo de sus labios entreabiertos", alteración que elimina la sinéresis, pero al precio de hacerle decir a Bécquer un despropósito: dormir al soplo en vez de dormir al blando arrullo...

Afán de lógica, gramaticalerías, presupuestos poéticos y retóricos distintos, dureza de oído, capricho puro y simple, combinados o solos, suelen producir alteraciones que destruyen la idea del poeta. Así el desfallece de 3:30, convertido en enardece. Así la "embriaguez de dolor" de 43:6, convertida en "embriaguez del dolor" 34 . Así el Dormida de 27:9, desastrosamente cambiado en Despierta.

Valdrá la pena considerar con algún mayor detalle otros casos, porque estoy seguro de que si se los ve de cerca no quedará duda de que las correcciones del Ms. no son de mano de Bécquer.

1) El artículo indefinido tiene, en las Rimas, una función muy precisa de indefinición, valga la perogrullada. El verso "Como nota de música lejana" no suena mal ciertamente, pero, aparte de que no es el que Bécquer escribió, carece de la vaguedad sutil que tiene el original: "Como una nota de lejana música" (55:3) ${ }^{35}$. Campillo condena-

(evidentemente porque las imprentas españolas no solían tener el signo $i$ ). Por cierto que quienes no creen, como no creo yo, que las alteraciones del Ms. sean obra de Bécquer, difícilmente podrán convencer a Díaz de que las diéresis son adición de Campillo: écómo decidir si los dos puntitos fueron trazados por el poeta o por el corrector?

32 Cf. en 3:49 el heptasílabo "palabras reunir", y en 32:5 el hendecasílabo "¿Quién reunió la tarde a la mañana?"

33 Cf. R. Esquer Torres, "Estudio estilístico de la Rima XLI de Bécquer", BSCC, 32 (1956), 169-180.

34 La corrección no figura en el Ms., sino en las Eds. En este caso imprime Díaz en el texto "de[1] dolor", enmendando, como él dice, "el lapsus del ms." De ninguna manera: "la embriaguez de dolor" y "la embriaguez del dolor" son cosas distintas, y Bécquer quiso decir indudablemente lo primero.

35 "Indiscutiblemente, el verso original supera en mucho al verso corregido", dice Benítez, p. 144. Estoy de acuerdo. Léase, además, toda la secuencia: "como una 
ba, por lo visto, lo que debió de considerar "abuso" del artículo. Cf. "unas palabras" > "breves palabras" (42:10); "como la imagen / que en un ensueño pasa, / como un rayo de luz tenue y difuso" > "que en leve ensueño pasa, / como rayo de luz..." (74:10-11); "obra de un cincel rudo" $>$ "de cincel rudo" (45:3).

2) La versión original de los versos 17-20 de la Rima 56 dice:

Así van deslizándose los días

unos de otros en pos,

hoy lo mismo que ayer... probablemente

mañana como hoy.

Campillo destruye la muy voluntaria imprecisión de Bécquer (análoga a la del final de la Rima 54) y, pensando quizá que el lector no iba a entender cómo se deslizaban los días del poeta, aclara y achata los dos últimos versos: "hoy lo mismo que ayer... y todos ellos / sin gozo ni dolor".

3) También hace explícito lo que Bécquer dejó ambiguo en el maravilloso final de la Rima 42:

Pasó la nube de dolor... Con pena

logré balbucear unas palabras...

Y... ¿qué habia de hacer? Era un amigo...

Me habia hecho un favor... Le di las gracias.

No creo que Bécquer se las hubiera dado a su corrector si hubiese visto el "favor" que le hizo con su retoque:

Pasó la nube de dolor... Con pena

logré balbucear breves palabras...

¿Quién me dio la noticia?... Un fiel amigo...

Me hacia un gran favor... Le di las gracias.

4) Bécquer tiene una peculiar predilección por la simetría, la similicadencia, la anáfora ${ }^{36}$. Baste pensar en los "Volverán..." de la Rima 53 o los "Mientras..." de la Rima 4. Las cuatro primeras estrofas de la Rima 2 muestran diáfanamente este afán de simetría:

Saeta que... cruza...

y que no se sabe dónde... se clavará;

Hoja que... arrebata el vendaval,

y que no hay quien diga el surco donde al polvo volverá;

Ola... que el viento riza...

y se ignora qué playa buscando va;

Luz que en cercos... brilla,

y que no se sabe de ellos cuál el último será.

nota de lejana música, / el eco de un suspiro. // El eco de un suspiro que conozco, / formado de $u n$ aliento que he bebido, / perfume de una flor que oculta crece / en un claustro sombrío".

36 Cf. Carlos Blanco Aguinaga; "La lucha con la palabra en Bécquer", CuA, 1955, núm. 3, 244-256, y Carlos Bousoño, "Las pluralidades paralelísticas de Bécquer", en Seis calas en la expresión literaria española, Madrid, 1951, pp. 189-227. 
Pues bien, Campillo destruye ya en el Ms. el segundo de los miembros: "sin que nadie acierte el surco", y en la Ed. completa su funesta labor" y no deja sano ninguno de los otros tres: "sin adivinarse dónde", "y no sabe...", "ignorándose cuál de ellos". Todo, evidentemente, por un prurito de corrección acedémica: le molestaría, por ejemplo, en "Saeta que... y que...", el ver que los dos que no eran homólogos. Hay otros casos parecidos. En la Rima 73, las tres repeticiones del estribillo "¡Dios mío, qué solos / se quedan los muertos!" van precedidas en el original por el verso "yo (o que) pensé un momento", pero Campillo, gratuitamente, prefirió poner la primera y la tercera vez "medité un momento" (vs. 24 y 76). También estuvo a punto de quedar estropeado el último verso de la más célebre de las Rimas, "así... no te querrán" (53:24), paralelo perfecto de los vs. 8 y 16, "ésas... no volverán". Campillo, atolondradamente, lo sustituyó en el Ms. por otro verso de su cosecha: "nadie así te amará". Sólo que en esta ocasión, algo - ¿tal vez el espíritu del poetą - le hizo mudar de opinión y lo obligó a imprimir lo que Bécquer había dicho: "así... no te querrán" ${ }^{38}$.

5) La Rima 48: "Como se arranca el hierro de una herida, / su amor de las entrañas me arranqué...", termina en el original con esta estrofa (vs. 9-12) :

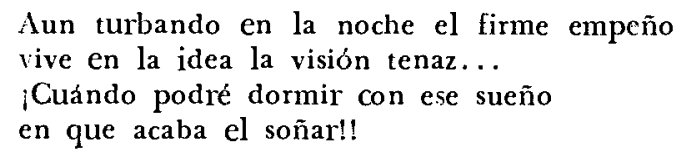

Como se ve, la precisión en la noche es importante: es de noche cuando la imagen que parecía arrojada, cuando el fuego que parecía apagado muestran que siguen "vivos" y presentes, y el "firme empeño" del poeta es turbado por sueños obsesivos. Campillo, por razones imposibles de imaginar, abarata una vez más la expresión. Escribe primero "Aun para combatir mi firme empeño / se alza en mi mente su visión tenaz", y luego, insatisfecho aún, retoca así el verso 10: "viene a mi mente su visión tenaz"39.

\footnotetext{
37 Me atengo a los datos de Benítez y de Díaz; D. Bordona dice que en los cuatro casos la corrección se hizo en la Ed.

38 Cf. infra, nota 41 .

39 Díaz es el único que aclara estas etapas de la corrección del v. 10. Según Benitez, el original decia "viene en la idea la visión tenaz", y se corrigió en "viene a mi mente su visión tenaz". D. Bordona dice lo mismo (sólo que, por error, da como versión original "st visión" en vez de "la visión"). O sea que ni D. Bordona ni Benitez registran el original vive ni el intermedio se alza. Supongo que el amontonamiento de correcciones les impidió ver claro. (Pero, desde luego, ni Bécquer ni Campillo pudieron haber usado el giro venir en).-Menciono aquí otra alteración que tiene que ver con noche, y acerca de la cual puede haber dudas. La Rima $7 I$ parece describir una alucinación nocturna. El poeta vaga, insomne, por los "misteriosos espacios que separan / la vigilia del sueño". Es cierto que luego dice que sus párpados velaban el reflejo "de la luz que entra al alma por los ojos", pero esta luz puede no ser la del día (o de la tarde), sino la de una lámpara. El co mienzo de la Rima, "No dormia: vagaba en ese limbo...", difícilmente puede referirse a una hora diurna. El caso es que la última estrofa comenzaba así en el
} 
6) He aquí la tercera estrofa de la Rima 52 en su forma original:

Nubes de tempestad que rompe el rayo $y$ en fuego enciende las sangrientas orlas, arrebatado entre la niebla oscura, llevadme con vosotras!

Tengo para mí que Campillo era algo tonto, y que no entendió bien el sentido de estos versos. Bécquer dice, por supuesto - con sintaxis algo galicista-, que el rayo rompe o desgarra las nubes y enciende en fuego sus orlas. Campillo comenzó por poner encienden en vez de enciende ${ }^{40}$, como si las orlas fueran las causantes del incendio en vez del rayo; y luego, cambiando de idea, y destruyendo, según su costumbre, la viveza de la imagen becqueriana, puso "y en fuego ornáis las desprendidas orlas", con lo cual hizo que sean las nubes las que encienden (las que "ornan", mejor dicho) sus propias orlas. Un verdadero desastre.

7) Otra corrección apresuradísima (y destructora) de Campillo es la del final de la Rima 67. Bécquer había escrito:

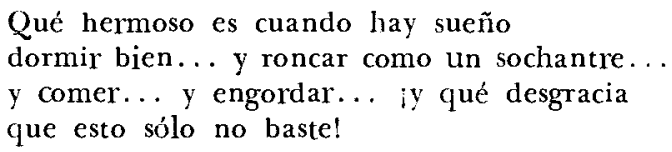

Campillo, denodadamente, "corrigiơ" el qué desgracia convirtiéndolo en qué fortuna. Pero luego, me imagino que a última hora, se dio cuenta ipor fin! de la ironía de la exclamación, y restauró en la Ed. lo que nunca debió haber tocado ${ }^{41}$.

Ms.: "Pasó la noche, y del olvido en brazos / cai cual piedra en su profundo seno: / dormí...", etc. Si, como creo, el ambiente de la Rima es nocturno, la expresión "Pasó la noche" es justa, y el sueño profundo que sigue a la alucinación ocurre en la madrugada. Ahora bien, según DíAz, la palabra Pasó fue tachada en el Ms. y sustituida por Entró ("Entró la noche..."), que es la que él da en el texto, naturalmente. Pero esta vez, como en el caso señalado supra, p. 409, nota 22, Bevítez cree posible que la corrección se deba a Bécquer: "El corrector desconocido acostumbra tachar las palabras que va a modificar, escribiendo la enmienda entre líneas $o$ al margen... Aquí, en cambio, sobre el texto original, cuya primera palabra es prácticamente ilegible, «Pasó (?) la noche y del olvido en brazos», alguien ha escrito, aprovechando los rasgos de la inicial mayúscula $P$, la variante Entró la noche y del olvido en brazos». El dibujo de la $E$ es similar al de otras grafias de Bécquer".

40 Caso parecido al de "cual átomos que agrupa / recóndita atracción" (3:60), que en las Eds. vino a ser "cual átomos que agrupan". Es verdad que D. Bordona, Benítez y Díaz leen unánimemente "encienden" en el Ms. original de la Rima 52. ¿No será que la $n$ se añadió después? (Sería muy extraño que Bécquer se hubiera equivocado así. Pero si se hubiera equivocado, habría que corregirlo). Es claro que el rayo es el sujeto de los dos verbos, rompe y enciende. Cf. otras imágenes parecidas: "mientras el sol las desgarradas nubes / de fuego y oro vista" (4:7-8), y "el sol besa a la nube en occidente / y de púrpura y oro la matiza" (9:3-4).

41 Me imagino que Díaz habrá tenido aquí, como en el ya señalado "así... no te querrán" de 53:24, unas tentaciones fortísimas de adoptar la lección tachada en el Ms. Pero tenía que ser congruente con su idea de que las correcciones son de la mano de Bécquer, y así perpetúa en su edición dos versos que ¡el mismo Campillo! 
8) El verso "y sin embargo guardábamos" (29:7), octosílabo perfecto, le sonó mal a Campillo, que debía ser muy duro de oreja, y así a parece sustituido en el Ms. por este otro octosílabo... de siete sílabas: "mas guardábamos ambos" 2 . Quienes cuidaron las "ediciones posteriores", como dice Díaz (supongo que quiere decir posteriores a la primera), se vieron obligados a remediar como Dios les dio a entender tamaño dislate, e imprimieron "mas guardábamos entrambos". Pero Díaz mismo, llevado de su idea fija, hace cometer a Bécquer esa enormidad métrica.

Y con esto llego a mi conclusión. Creo que bastarían las últimas "enmiendas" comentadas, o incluso una sola, la última, para echar por tierra la teoría de que las correcciones del Ms. son de la mano de Bécquer. El oído musical del poeta se hubiera horrorizado al escuchar ese heptasílabo intruso en vez del octosílabo original. Ahora bien, es claro que la misma mano que corrompió el verso $29: 7$ fue la que modificó o deturpó también los demás.

Aun así, voy a desarrollar un poco más mi argumento. Sostiene Díaz, en uno de los párrafos que copié al principio, que las variantes que aparecen en las Eds. se diferencian de las del Ms. en que, por una parte, son "académicas y exteriores" y, por otra, no tan exteriores, puesto que a menudo "alteran el sentido original". Mis conclusiones son distintas. La variante de la Ed. en 27:9 (Despierta en vez de Dormida) altera ciertamente el sentido original, pero también lo altera la variante del Ms. en 67:15 (qué fortuna en vez de qué desgracia). De hecho, encuentro que las alteraciones más graves, que son las que he comentado al final, numerándolas de 1 a 8 , se hicieron todas en el Ms., salvo las de la Rima 53, hechas parte en el Ms. y parte en la Ed. Y lo que ocurre en esta Rima 53 muestra justamente que no hay diferencia entre unas correcciones y otras. La misma mano que cambió "y que no hay quien diga el surco" en "sin que nadie acierte el surco" (Ms.), fue la que

repudió por impertinentes y disparatados.-Hay otros casos de arrepentimiento: los versos "todo lo que los dos hemos callado / lo tenemos que hablar" (37:23-24) no le gustaron al corrector, que los alteró así en el Ms.: "todo cuanto los dos hemos callado / alli lo hemos de hablar", pero se dio cuenta, a tiempo, de la repetición de hemos (y quizá de que la estrofita comenzaba con otro alli) y regresó, en la Ed., a la lección original. El giro cansado se halla (57:3) fue caprichosamente convertido en se halla cansado, pero en la Ed. se imprimió lo que Bécquer había escrito. Tampoco estos dos arrepentimientos tienen cabida, por supuesto, en la edi ción de Díaz.-En cuanto a la alteración de la Rima 67, fue señalada por D. BoRDoNA: "Campillo había enmendado el verso... sustituyendo la palabra fortuna por desgracia. Pero, felizmente, se respetó en las impresiones la idea expresada por Bécquer". Benítez, p. 144 y Tabla, afirma que esta "nota aclaratoria" de D. Bordona es "confusa". No veo por qué. La "idea expresada por Bécquer" es la lección original (qué desgracia), y esa idea original fue la que, "felizmente", se respetó en las impresiones. El confuso es Benitez, que en la p. 144 explica que "esa corrección [qué fortuna] no pasa a las ediciones", y en la Tabla pone el qué fortuna en la columna de "Variantes que presentan las ediciones corrientes".

$12 \mathrm{La}$ razón del cambio parece ser que a Campillo, por prurito académico, le molestó el sin embargo usado con el valor de un simple 'pero'. Cf. también "no obstante, amada mía" > "pero yo, amada mía" (26:2), y "No obstante al despertar exclamé: Alguno..." > "Dormi y al despertar exclamé: Alguien..." (71:23). 
cambió "y que no se sabe dónde" en "sin adivinarse dónde" (Ed.) . Hay una perfecta continuidad entre las dos alteraciones. Esta continuidad se puede apreciar a cada paso. Tan académica y exterior es la corrección del Ms. "No obstante al despertar" > "Dormi y al despertar" (71:23) como la corrección de la Ed. "No obstante, amada mía" > "Pero yo, amada mía" (26:2) . Los ejemplos son fáciles de multiplicar. Repetición de sonidos: 57:4 "porque aunque es la verdad que..." > "pues aunque es..." (Ms.) $=2: 8$ "donde al polvo volverá" $>$ "donde a caer volverá" (Ed.) ; 75:19 "Lo que sé es que..." > "Pero sé qué..." (Ms.) $=41.3$ "que estrellarte o que abatirme" $>$ "que estrellarte o abatirme" (Ed.). Giros impersonales: 76:27 se llega > llegamos (Ms.) $=4: 21$ se sienta $>$ sintamos (Ed.). Expresiones demasiado familiares: 8:5 y. 14 se me antoja $>$ me parece (Ms.) $=72: 25$ por señas $>$ por cierto (Ed.). Imágenes "impropias": 67:8 "el perfume beber" $>$ "el perfume aspirar" (Ms.) $=4: 21$ "se rie el alma" > "se alegra el alma" (Ed.).

Por otra parte, el caso de las enmiendas que presenta el Ms. en $37: 24,53: 24,57: 3$ y $67: 15$, mientras que la Ed. vuelve al texto original antes de ser alterado (cf. supra, pp. 415-416, nota 41), es un argumento fuerte contra la idea de que las correcciones son de Bécquer, y en favor de la teoría que hace de Campillo el autor de esas correcciones a la vez que de las que figuran en la edición de 1871. La única explicación coherente es que Campillo desechó en esos cuatro casos sus enmiendas absurdas y volvió al texto original de Bécquer.

Y están, finalmente, las tres poesías que se suprimieron por demasiado "sarcásticas". La mano que, escandalizada, tachó en el Ms. la amarga rima "Una mujer me ha envenenado el alma...", es la misma que eliminó de la Ed. las otras dos, igualmente amargas, "Dices que tienes corazón..." y "Fingiendo realidades..."

Temo haberme alargado demasiado. Pero, como dije al principio, lo que está en juego es la autenticidad textual de una poesía admirable. Y además, es muy posible que el merecidísimo prestigio de José Pedro Díaz (que yo quisiera dejar intacto) y la difusión y popularidad de la colección de Clásicos castellanos induzcan a otros editores a seguir el ejemplo dado en el volumen que he comentado. En tal caso, quizá las observaciones que he hecho no serán del todo ociosas.

El Colegio de México.

Antonio Alatorre 